\title{
Factors Affecting Safety and Efficacy of PCNL in Lower Calyceal Stones
}

\author{
OMAR A. DARWISH, M.Sc.; AHMED M. EL-SAKKA, M.D.; MOHAMED O. ABU FARHA, M.D. and \\ OSAMA M. EL-GAMAL, M.D.
}

The Department of Urology, Faculty of Medicine, Tanta University

\begin{abstract}
Background: The management of lower calyceal stones is still one of today's topics in endourology. Percutaneous nephrolithotomy (PCNL) is found to be a highly effective procedure in treatment of lower pole calculi. However, many factors are affecting the stone free rate and complication rate.

Aim of the Study: The aim of this study was to evaluate the factors that affect the safety and efficacy of PCNL in lower calyceal stones more than $2 \mathrm{~cm}$.

Patients and Methods: Forty eight patients with lower pole calculi more than $2 \mathrm{~cm}$ underwent percutaneous nephrolithotomy. Preoperative, operative and postoperative data were reported. Multivariate analyses as well as univariate analyses were used to investigate the effects of different variables on residual stones and blood transfusion rate. These factors include age, sex, laterality, body mass index, history of ipsilateral open renal surgery, operative time, lower pole parenchymal thickness, presence of hydronephrosis, stone burden and stone density.

Results: Unvariate analysis determined that stone burden $(p<0.001)$, stone count $(p<0.02)$, lower pole parenchymal thickness $(p<0.03)$, presence of hydronephrosis $(p<0.001)$ and operative time $(p<0.04)$ were statistically significant with the stone free rate. Multivariate analysis revealed that, presence of hydronephrosis (odds ratio [OR]: $0.365,95 \%$ confidence interval [CI]: $0.104-0.652, p=0.034)$, lower pole parenchymal thickness (OR: $0.347,95 \%$ CI: $0.241-0.874, p=0.04$ ), the operative time (OR: $0.587,95 \%$ CI: $0.149-0.857, p=0.032$ ), stone count (OR: $0.647,95 \%$ CI: $0.205-0.874, p=0.028)$ and stone burden (OR: $0.428,95 \%$ CI: $0.169-0.985, p=0.021$ ) were significant independent factors influence stone residual. Univariate analysis determined that stone burden $(p<0.001)$, body mass index $(p<0.015)$, history of ipsilateral open renal surgery $(p<0.017)$, lower pole parenchymal thickness $(p<0.001)$ and operative time $(p<0.015)$ correlated with blood transfusion rate. Multivariate analysis revealed that stone burden (OR: $0.628,95 \%$ CI: $0.149-0.852, p=0.014$ ), operative time (OR: $0.452,95 \%$ CI: $0.125-0.856, p=0.002$ ), lower pole parenchymal thickness (OR: $0.365,95 \%$ CI: $0.014-0.836, p=0.002$ ), body mass index (OR: $0.589,95 \%$ CI: $0.159-0.744, p=0.038$ ) and history of ipsilateral surgery (OR: $0.635,95 \%$ CI: 0.258 $0.825, p=0.017$ ) were significant independent factors influence blood transfusion rate.
\end{abstract}

Correspondence to: Dr. Omar A. Darwish, The Department of Urology, Faculty of Medicine, Tanta University
Conclusion: PCNL is a safe and effective procedure for lower calyceal stones more than $2 \mathrm{~cm}$. The stone free rate in the study was affected mainly by the stone burden and the operative time, the stone count, the degree of hydronephrosis and the lower pole parenchymal thickness were also involved. The blood transfusion rate was also affected by the stone burden, the operative time, the BMI, history of ipsilateral open renal surgery and the lower pole parenchymal thickness.

Key Words: Lower calyceal stones - PCNL - Stone free rate - Blood transfusion.

\section{Introduction}

UROLITHIASIS is a common medical problem with a prevalence of approximately $2 \%$ to $3 \%$ in the general population. Renal stones can cause serious morbidity, pain, haematuria, infection and decreased renal function. The great expansion in minimally invasive techniques has led to the decrease in open surgery.

Extracorporeal shock wave lithotripsy (ESWL) has been introduced as an alternative approach and disintegrates stones in the kidney and the upper urinary tract through the use of shock waves. However, there are several factors which will affect the choice of treatment for kidney stones including the size, location, and stone composition. Lower calyceal stones have a lower clearance rate after ESWL and the stone size for treatment in this location is generally limited to $10 \mathrm{~mm}[\mathbf{1 , 2}]$.

PCNL is indicated for patients with large kidney and upper urinary tract stone. The main advantage of PCNL is the higher success rate for these larger stone $[3,4]$ as it is not dependent on the stone burden or composition [5].

Lower pole calyceal stones are difficult to be cleared; the general consensus favors PCNL over SWL for clearing lower pole stones. Again PCNL is preferred for the management of multiple renal stones or stones in dependent areas in the kidney 
[6]. Economically, PCNL is more cost-effective than SWL and RIRS for lower pole calyceal stones larger than $2 \mathrm{~cm}$ [7].

Although PCNL is considered less invasive treatment option with higher stone free rate and earlier return to daily life, it is still challenging to the urologist in treating large stones [8]. As its high SFR is counterbalanced by the risk of a high morbidity rate and many efforts have been made to decrease the morbidity associated with this technique [9].

In this study, patient-related, stone-related and procedure-related factors that influence residual stones and blood transfusion rate were evaluated.

\section{Patients and Methods}

This prospective randomized study included 45 patients admitted into Urology Department, Tanta university hospital suffering from lower calyceal stones larger than $2 \mathrm{~cm}$. They were scheduled for PCNL during the period from March 2016 to March 2017.

Inclusion criteria: Adult patients with lower calyceal stone larger than $2 \mathrm{~cm}$ already were booked for PCNL.

Exclusion criteria: Patients with complete staghorn stone, renal anomalies, stones need multiple accesses or with uncontrolled bleeding disorders.

Preoperative evaluation: Every patient was preoperatively evaluated with complete history taking, general and local examination. Routine laboratory investigations, plain urinary tract film and spiral non contrast CT scan abdomen and pelvis were done. Preoperative urinary tract infection was treated with culture specific antibiotic.

\section{Operative procedure:}

Prophylactic amoxicillin and clavulanate $1.2 \mathrm{gm}$ IV was given night before the procedure as well as gentamycin 160mg was given during anesthetic induction. Under general anesthesia in lithotomy position every patient subjected to cystoscopy with identification of the ureteric orifice. Under fluoroscopy, open tip ureteric catheter $(6 \mathrm{~F})$ was advanced over the guide wire to the renal pelvis and fixed with Foley's catheter. IV set was connected to the distal end of the open tip ureteric catheter for dye injection during kidney puncturing. Patient was then turned prone for PCNL with proper padding of pressure point areas. A dilated urografine (1:3) was injected through the ureteric catheter for opacification of the collecting system and the desired posterior inferior calyx was punctured by 18 gauge
Chiba needle. Proper calyceal puncture was confirmed with free flow of urine through the needle and $\mathbf{J}$ tip guide wire was placed. Small skin and subcutaneous incision was done using scalpel then tract dilatation was achieved by facial dilator up to $12 \mathrm{~F}$ followed by balloon dilatation or using telescoping metal dilators under fluoroscopic control to 30F. An Amplatz sheath was passed over the last dilator or the inflated balloon. In obese patients; the Amplatz sheath was sutured to skin to prevent its retraction. Either pneumatic or ultrasonic lithotriptors were used to break stones into manageable fragments. Small fragments were extracted with grasping forceps. At the end of the procedure a nephrostomy (16F) Foley's catheter was placed into renal pelvis through the Amplatz sheath. A nephrostogram was done by injecting urografin dye through the catheter, and then the nephrostomy tube was sutured to the skin. DJ was inserted routinely in every patient.

Postoperative evaluation: Immediately postoperative, I.V. fluids were administered in the first postoperative day. Vital data were measured. Pain control was achieved (NSAID) and Antibiotic (ceftriaxone $1 \mathrm{gm}$ per day) was administered. Haemoglobin and haematocrit levels were done 8 hours after operation. Urine output, volume and colour through urethral catheter and the nephrostomy tube were monitored every 8 hours or more frequent in critical cases. Any case with excessive bleeding through the nephrostomy tube, the tube was clamped for 6 hours. Blood transfusion was given in cases with persistent bleeding, haemodynamic instability or significant haematocrit drop.

After 24 hours, PUT was done to assess postoperative residual stones in case of radiopaque stones, Removal of the urethral catheter and Clamping of the nephrostomy tube and monitoring of pain, fever or urine leakage.

After 48 hours, in uncomplicated case, the nephrostomy tube was removed and the patient sent home. The cases that had perforation of pelvicalyceal system with extravasation detection during intraoperative nephrostogram, removal of the nephrostomy tube was delayed 3-4 days. Cases with residual stones not amenable to ESWL were scheduled for 2 nd look PCNL one week later.

Follow-up, before discharging home, every patient was instructed to contact us as soon as possible in case of significant haematuria, fever or significant pain. One week after discharge, every patient was seen in the outpatient clinic for assessment of nephrostomy tract, urine leakage, pain or fever. Then 3 weeks later, patients who had radi- 
olucent stones underwent non contrast pelviabdomenal CT for evaluation of significant residual stones (more than 4mm) and DJ retrieval was performed. However ESWL was conducted to the indicated patient before DJ retrieval.

Statistical analysis: Statistical analysis was done using IBM SPSS software version 20.0. (Armonk, NY: IBM Corp). Categorical variables were compared with the chi-squared test or Fisher's exact test and continuous variables were compared with the $t$-test. $p<0.05$ was considered statistically significant.

\section{Results}

Patients related, stone related and procedure related factors are summarized in (Table 1). From the univariate analysis, there was siginificant association between stone burden, stone count, lower pole parenchymal thickness, operative time, presence of hydronephrosis and stone free rate $(p=$ $0.001 ; p=0.02 ; p=0.03 ; p=0.001$ and $p=0.04$ respectively). Univariate analysis is illustrated in (Table 2). Multivariate analysis included factors with $p<0.05$ showed that the stone burden was the most influential predictor of stone free rate (OR 0.428, $95 \%$ CI $0.169-0.985, p 0.02)$. Multivariate analysis for stone free rate is illustrated in (Table 3).

Table (1): Patient related, stone related and procedure related factors.

\begin{tabular}{|c|c|}
\hline Variable & Mean \pm SD or $N(\%)$ \\
\hline No. of patients & 45 \\
\hline $\begin{array}{l}\text { Gender: } \\
\text { Males } \\
\text { Females }\end{array}$ & $\begin{array}{l}21(46.7) \\
24(53.3)\end{array}$ \\
\hline Age (years) & $52.4 \pm 11.9$ \\
\hline $\begin{array}{l}\text { BMI: } \\
\begin{array}{l}25-29 \mathrm{~kg} / \mathrm{m}^{2} \\
30-34.5 \mathrm{~kg} / \mathrm{m}^{2} \\
35-39.5 \mathrm{~kg} / \mathrm{m}^{2}\end{array}\end{array}$ & $\begin{array}{l}26(57.7) \\
16(35.5) \\
3(6.7)\end{array}$ \\
\hline $\begin{array}{l}\text { History of open surgery: } \\
\text { Positive } \\
\text { Negative }\end{array}$ & $\begin{array}{l}19(42.2) \\
26(57.8)\end{array}$ \\
\hline Stone Burden $\left(\mathrm{mm}^{2}\right)$ & $753 \pm 259.18$ \\
\hline $\begin{array}{l}\text { Stone count: } \\
\text { Single } \\
\text { Multiple }\end{array}$ & $\begin{array}{l}24(53.3) \\
21(46.7)\end{array}$ \\
\hline $\begin{array}{l}\text { Stone density }(\mathrm{HU}) \\
\text { Lower pole thickness (mm) }\end{array}$ & $\begin{array}{l}1032.9 \pm 236.82 \\
14 \pm 1.04\end{array}$ \\
\hline $\begin{array}{l}\text { Hydronephrosis: } \\
\text { No/mild } \\
\text { Moderate/severe }\end{array}$ & $\begin{array}{l}26(57.7) \\
19(42.3)\end{array}$ \\
\hline $\begin{array}{l}\text { Laterality, } N(\%): \\
\text { Right } \\
\text { Left }\end{array}$ & $\begin{array}{l}21(46.7) \\
24(53.3)\end{array}$ \\
\hline $\begin{array}{l}\text { Operative time }(\mathrm{min}) \\
\text { Perforation } \\
\text { Fever } \\
\text { Significant residual stones } \\
\text { Blood transfusion }\end{array}$ & $\begin{array}{l}83.3 \pm 24 \\
6(13.3) \\
10(22.2) \\
12(26.6) \\
4(8.9)\end{array}$ \\
\hline
\end{tabular}

Table (2): Univariate analysis illustrates factors affecting stone free rate and residual stone.

\begin{tabular}{|c|c|c|c|}
\hline Variable & Stone free & Stone residual & $p$ \\
\hline \multicolumn{4}{|l|}{ Gender, $N(\%)$ : } \\
\hline Males & $15(45.5)$ & $6(50)$ & 057 \\
\hline Females & $18(54.57)$ & $6(50)$ & \\
\hline \multicolumn{4}{|l|}{ Age: } \\
\hline Range & $28-68$ & $40-64$ & 0.78 \\
\hline Mean $\pm \mathrm{SD}$ & $51.79 \pm 13.19$ & $54.08 \pm 8.06$ & \\
\hline \multicolumn{4}{|l|}{$B M I$ : } \\
\hline Range & $26-35$ & $25-36$ & 0.52 \\
\hline Mean \pm SD & $29.18 \pm 2.65$ & $29.83 \pm 3.83$ & \\
\hline \multicolumn{4}{|l|}{ History of open } \\
\hline \multicolumn{4}{|l|}{ surgery, $N(\%)$ : } \\
\hline Positive & $12(36.4)$ & $7(58.3)$ & 0.18 \\
\hline Negative & $21(63.6)$ & $5(41.7)$ & \\
\hline \multicolumn{4}{|l|}{ Stone Burden: } \\
\hline Range & $300-1250$ & $660-1450$ & $0.001^{*}$ \\
\hline Mean \pm SD & $658.55 \pm 206.28$ & $966.4 \pm 260.62$ & \\
\hline \multicolumn{4}{|l|}{ Stone count, $N(\%)$ : } \\
\hline Single & $21(63.6)$ & $3(25)$ & $0.02 *$ \\
\hline Multiple & $12(36.4)$ & $9(75)$ & \\
\hline \multicolumn{4}{|l|}{ Stone density: } \\
\hline Range & $350-1350$ & $630-1270$ & 0.87 \\
\hline Mean \pm SD & $1035.64 \pm 217.22$ & $1023.83 \pm 210.46$ & \\
\hline \multicolumn{4}{|l|}{ Lower pole thickness: } \\
\hline Range & $12-15$ & $11-16$ & $0.03 *$ \\
\hline Mean \pm SD & $14.15 \pm 0.76$ & $13.42 \pm 1.51$ & \\
\hline \multicolumn{4}{|l|}{ Hydronephrosis, } \\
\hline \multicolumn{4}{|l|}{$N(\%)$ : } \\
\hline No/mild & $8(24.2)$ & $12(100)$ & $0.001 *$ \\
\hline Moderate/severe & $25(75.8)$ & 0 & \\
\hline \multicolumn{4}{|l|}{ Laterality, $N(\%)$ : } \\
\hline Right & $16(48.5)$ & $5(41.7)$ & 0.68 \\
\hline Left & $17(51.5)$ & $7(58.3)$ & \\
\hline \multicolumn{4}{|l|}{ Operative time: } \\
\hline Range & $55-118$ & $61-120$ & $0.04 *$ \\
\hline Mean \pm SD & $79.39 \pm 22.29$ & $95.92 \pm 25.26$ & \\
\hline
\end{tabular}

Table (3): Multivariate analysis included factors affecting the residual stones.

\begin{tabular}{|c|c|c|c|c|}
\hline \multirow{2}{*}{ Residual stone } & \multirow{2}{*}{ OR } & \multicolumn{2}{|c|}{$\begin{array}{l}\text { Multivariate } \\
(95 \% \mathrm{CI})\end{array}$} & \multirow{2}{*}{$p$-value } \\
\hline & & Lower & Upper & \\
\hline Hydronephrosis & 0.365 & 0.104 & 0.652 & $0.034 *$ \\
\hline $\begin{array}{l}\text { Lower pole Parenchymal } \\
\text { thickness }\end{array}$ & 0.347 & 0.241 & 0.874 & $0.041^{*}$ \\
\hline Operative time & 0.587 & 0.149 & 0.857 & $0.032 *$ \\
\hline Stone count & 0.647 & 0.205 & 0.874 & $0.028 *$ \\
\hline Stone burden & 0.428 & 0.169 & 0.985 & $0.021 *$ \\
\hline
\end{tabular}

*: Statistically significant at $p \leq 0.05$. 
Regarding blood transfusion, the univariate analysis revealed that there was significant association between stone burden, lower pole parenchymal thickness, BMI, history of ipsilateral open renal surgery, operative time and stone free rate $(p=0.001, p=0.001, p=0.015, p=0.017$ and $p=0.015$ respectively) (Table 4). Multivariate analysis included factors with $p<0.05$ showed that the operative time was the most influential factor for blood transfusion (OR 0.452, 95\% CI 0.125-0.856, $p=0.002)($ Table 5).

Table (4): Univariate analysis illustrates factors affecting blood transfusion.

\begin{tabular}{|c|c|c|c|}
\hline \multirow{2}{*}{ Variable } & \multicolumn{2}{|c|}{ Blood transfusion } & \multirow{2}{*}{$p$} \\
\hline & Positive & Negative & \\
\hline \multicolumn{4}{|l|}{ Gender, $N(\%)$ : } \\
\hline Males & $3(75)$ & $18(43.9)$ & 0.23 \\
\hline Females & $1(25)$ & $23(56.1)$ & \\
\hline \multicolumn{4}{|l|}{ Age: } \\
\hline Range & $28-68$ & $40-64$ & 0.56 \\
\hline Mean \pm SD & $55.66 \pm 12.23$ & $49.75 \pm 10.21$ & \\
\hline \multicolumn{4}{|l|}{ BMI: } \\
\hline Range & $30-36$ & $25-35$ & 0.015 \\
\hline Mean \pm SD & $32.75 \pm 3.2$ & $29.02 \pm 2.78$ & \\
\hline \multicolumn{4}{|l|}{ History of open } \\
\hline \multicolumn{4}{|l|}{ surgery, $N(\%)$ : } \\
\hline Positive & $4(100)$ & $15(36.6)$ & 0.017 \\
\hline Negative & 0 & $26(63.4)$ & \\
\hline \multicolumn{4}{|l|}{ Stone Burden: } \\
\hline Range & $910-1450$ & $300-1300$ & 0.001 \\
\hline Mean $\pm \mathrm{SD}$ & $1167.5 \pm 223.96$ & $699.07 \pm 223.96$ & \\
\hline \multicolumn{4}{|l|}{ Stone count, $N(\%)$ : } \\
\hline Single & $1(25)$ & $23(56.1)$ & 0.23 \\
\hline Multiple & $3(75)$ & $18(43.9)$ & \\
\hline \multicolumn{4}{|l|}{ Stone density: } \\
\hline Range & $1000-1270$ & $350-1350$ & 0.53 \\
\hline Mean $\pm \mathrm{SD}$ & $1097.5 \pm 128.16$ & $1026.15 \pm 219.69$ & \\
\hline \multicolumn{4}{|l|}{ Lower pole thickness: } \\
\hline Range & $13-16$ & $11-15$ & 0.001 \\
\hline Mean \pm SD & $14.63 \pm 0.81$ & $13.59 \pm 0.98$ & \\
\hline \multicolumn{4}{|l|}{ Hydronephrosis, } \\
\hline \multicolumn{4}{|l|}{$N(\%):$} \\
\hline No/mild & $4(100)$ & $16(39)$ & 0.07 \\
\hline Moderate/severe & 0 & $25(61)$ & \\
\hline \multicolumn{4}{|l|}{ Laterality, $N(\%)$ : } \\
\hline Right & 0 & $21(51.2)$ & 0.06 \\
\hline Left & $4(100)$ & $20(48.8)$ & \\
\hline \multicolumn{4}{|l|}{ Operative time: } \\
\hline Range & $110-120$ & $55-120$ & 0.015 \\
\hline Mean \pm SD & $116.5 \pm 4.73$ & $9580.61 \pm 252.67$ & \\
\hline
\end{tabular}

*: Statistically significant at $p \leq 0.05$.
Table (5): Multivariate analysis included factors affecting blood transfusion rate.

\begin{tabular}{|c|c|c|c|c|}
\hline \multirow{2}{*}{ Blood transfusion } & \multirow{2}{*}{ OR } & \multicolumn{2}{|c|}{$\begin{array}{c}\text { Multivariate } \\
(95 \% \mathrm{CI})\end{array}$} & \multirow{2}{*}{$p$-value } \\
\hline & & Lower & Upper & \\
\hline Previous surgery & 0.635 & 0.258 & 0.825 & $0.017 *$ \\
\hline BMI & 0.589 & 0.159 & 0.744 & $0.038^{*}$ \\
\hline $\begin{array}{l}\text { Lower pole Parenchymal } \\
\text { thickness }\end{array}$ & 0.365 & 0.014 & 0.836 & $0.012 *$ \\
\hline Operative time & 0.452 & 0.125 & 0.856 & $0.002 *$ \\
\hline Stone burden & 0.628 & 0.149 & 0.852 & $0.014 *$ \\
\hline
\end{tabular}

*: Statistically significant at $p \leq 0.05$.

\section{Discussion}

Lower calyceal stones continue to pose a dilemma owing to the dependent anatomical location and difficulty in clearance of stone fragments. Sampaio and Aragao [10] first described the anatomical factors that would impede gravitydependent drainage of stones from the lower pole calices. The goal of lower calyceal stone management is to achieve maximal stone clearance with minimal morbidity [3]. Percutaneous nephrolithotomy does not need a favorable anatomy and the diversity of stone nature does not hamper clearance rate [11].

According to the AUA guidelines [12] for lower calyceal stone treatment, ESWL or RIRS should be offered to patients with symptomatic $\leq 10 \mathrm{~mm}$ lower pole renal stones, patients with lower pole stones $>10 \mathrm{~mm}$ in size, should not be offered SWL the first line therapy and be informed that PCNL has a higher stone-free rate but greater morbidity. Patients with lower pole renal stones more than $2 \mathrm{~cm}$ should be offered PCNL as the first line therapy. Although PCNL is the gold standard treatment of renal stones, many factors are affecting stone free rate and complication rate [13].

In this study, the stone stone free rate was $73.3 \%$; this was due to using the pneumoclast in some patients. A study by Sanguedolce F. et al. [14] reported a stone free rate of $88.9 \%$. This difference may be due to larger number of patients in their study.

No major intraoperative complications were recorded in our study. Pelivcalyceal perforation in our study occurred in $13.3 \%$ of patients, due to high pressure irrigation system and using Alkan metal dilators. In a study by Seitz C et al. [15] reported pelvicalyceal system perforation in $5.3 \%$ of cases due to using low pressure irrigation flow 
system. Blood transfusion was reported in $8.9 \%$ of patients in our study. In study by Chibber P. J. [11] reported blood transfusion in $18 \%$ of cases. This discrepancy is attributed to the larger number of patients included in his study.

In the current study, minor postoperative complications in the form of postoperative fever and pain occurred in $22.2 \%$ of patients perhaps due to routine insertion of DJ stents and nephrostomy tube for all cases to avoid the possibility of ureteric obstruction by any small residual stones. However, Rashid A.O. and Fakhulddin S. [16] reported postoperative fever in $28.33 \%$ of patients may be due to longer duration of the procedure. Zhou Y et al., [17] demonstrated that no advantage of DJ ureteric stents over ureteric catheter in uncomplicated cases. Karadag A et al. [18] determined that tubeless PCNL in selected uncomplicated cases has advantages over conventional PCNL as a lesser postoperative pain, shorter hospital stay and shorter time of urinary leakage.

In this study, the age, sex and the laterality had no impact neither on the stone free rate nor on blood transfusion rate. These findings agree with that of Atmoko W et al. [19]. Furthermore, we found no correlation between BMI and stone free rate. However, BMI was associated with increased blood transfusion rate. These findings agree with Zhou $\mathrm{X}$ et al. [20] who demonstrated that PCNL in obese and morbidly obese patients yields a stone-free rate that is comparable to that achieved in nonobese one. Contrary to our finding, Ş imşek A et al. [21] reported that BMI does not affect the blood transfusion rate in PCNL.

In the present study, history of ipsilateral open renal surgery had no impact on stone free but it affected blood transfusion rate may be due to chronic inflammation, previous adhesions and neovascularization after previous operation. Reddy S.V. and Basha A. [22] demonstrated that previous open stone surgery or PCNL did not affect subsequent PCNL results. However, Shah et al. [23] Margel et al. [24] demonstrated in their studies that anatomical changes after open stone surgery such as infundibulum stenosis, perinephric fibrosis, bowel displacement and incisional hernia may decrease PCNL free rate after PCNL. Ozgorl F. et al. [25] reported increased blood transfusion rates in patients with previous ipsilateral surgery.

Stone burden in the present study was found to be the most influential factors affecting stone free rate with a critical stone burden of $750 \mathrm{~mm}^{2}$ above which the stone free rate decreased and complications increased This is in agreement with El-Nahas AR et al. [13] found an association between the stone burdens with a stone-free rate. Akman T. et al. [26] detected that stone burden is one of the predictive factors for blood transfusion and mean haematocrit drop. In addition there was a positive correlation between the stone count and the stone free rate however there was no correlation between stone count and blood transfusion rate. Zhu Z. et al. [27] demonstrated that an increased stone number was associated with decreased stonefree rates after PCNL but El-Nahas AR et al. [28] reported that increasing stone count is associated with increased blood transfusion rate.

In our study the mean HU values were approximately similar in stone-free patients, patients with residual stones after PCNL $(1029 \pm 231-1038 \pm 183$ respectively). Anastasiadis A et al., [29] evaluated patients according to $\mathrm{HU}<1250$ and $\mathrm{HU}>1250$ and found similar stone-free rate. We also, did not find any association between stone density and blood transfusion rate. While Gucuk et al., [30] have suggested that PCNL is a more efficient method for stones with higher HU values. In ROC analysis, they found the cut off value for $\mathrm{HU}$ to be 677.5. They suggested that when the HU value was under the cut off, the residual stone increased by 2.65 . They explained this efficiency by the opacity and visibility of the stones with higher $\mathrm{HU}$ values. Furthermore, they observed a positive correlation between $\mathrm{HU}$ values and blood transfusion due to hematocrit decrease which might have been related to the longer duration of surgery required to fragment the higher density stones, the requirement for more energy to fragment the denser stones, and the consequent increase in kidney traumatization in the high HU group.

In the present study, there was a reversed correlation between degree of hydronephrosis and the stone free rate after PCNL. This finding agree with that of Aminsharifi A. et al., [31] who found that with increase of the degree of hydronephrosis, stone scattering occurred during stone fragmentation with subsequent decrease in stone free rate. But we did not found any association between the degree of hydronephrosis and blood transfusion rate. Also, Akman T. et al., [26] demonstrated that the presence of hydronephrosis was not a risk factor for total blood loss. On the other hand, Rifaioglu M. et al., [32] demonstrated that the grade of hydronephrosis may affect bleeding indirectly due to patients' severe stone load, which causes prolonged operation time. 
This study demonstrated that there is significant correlation between stone free rate as well as blood transfusion rate and parenchymal thickness during PCNL. Tepeler et al., [33] observed that postoperative hematocrit drop and blood transfusion rate increase in parallel with the increase in renal parenchymal thickness but there was no association with the stone free rate. Nevertheless Karalar M et al., [34] found that the stone-free rate was higher in patients with thicker parenchyma explained this situation by those patients who have thicker renal parenchyma having a lower stone burden.

We found in a reversed correlation between operative time and the stone free rate. Our mean operative time was $83 \pm 24$. We demonstrated a cutoff value of $86 \mathrm{~min}$ above which stone free rate decreases and complications increased. Falahatkar $S$ et al., [35] demonstrated that the duration of the operation is an important factor in determining outputs and complications associated with PCNL. However, Huang SW et al., [36] estimated a shorter operative time, with a mean operating time of $63.5 \pm 11.8$ minutes due to direct puncture to the stone without previous insertion of ureteral catheter. Moreover, we found that the operative time was the most influential factor affecting blood transfusion rate. Yamaguchi A et al., [37] who found in their study that patients whose operations lasted longer than $75 \mathrm{~min}$ had statistically significantly more severe postoperative blood transfusion compared with those whose operative time was shorter than 50min and the risk of more postoperative blood transfusion increased even further for those whose operative time was more than $115 \mathrm{~min}$ there.

Conclusion: PCNL is a safe and effective procedure for lower calyceal stones more than $2 \mathrm{~cm}$. The stone free rate in the study was affected mainly by the stone burden and the operative time, the stone count, the degree of hydronephrosis and the lower pole parenchymal thickness were also involved. The blood transfusion rate was also affected by the stone burden, the operative time, the BMI, history of ipsilateral open renal surgery and the lower pole parenchymal thickness.

\section{References}

1- ALBALA D.M., ASSIMOS D.G., CLAYMAN R.V., et al.: Lower pole I: A prospective, randomized trial of ESWL and PCNL for lower pole nepphrolithiasis-initial results. J. Urol., 166: 2072-80, 2001.

2- TISELIUS H.G., ACKERMANNE D., ALKEN P., et al: Guidelines on urolithiasis. http://www.uroweborg /fileadmin/user_upload/Guidelines/18\%20Urolithiasis.pdf, 2006.

3- MAY D.J. and CHANDHOKE P.S.: Efficacy and costeffectiveness of extracorporeal shock wave lithotripsy for solitary lower pole renal calculi. J. Urol., 159: 24-27, 1998.

4- NETTO R.N., CLARO J.F., LEMOS G.C., et al: Renal calculi in lower pole calices what is the best method of treatment. J. Urol., 146: 721-3, 1991.

5- PEARLE M.S., CALHOUN E.A., CURHAN G., et al.: Ch. 8: Urolithiasis", pp. 283-319.

6- TURK C., KNOLL T., PETRIK A., et al.: Guidelines on Urolithiasis. EAU Guidelines. http://uroweb.org/wpcontent/uploads/22-Urolithiasis LR full, 2015.

7- HYAMS E.S. and SHAH O.: Percutaneous Nephrostolithotomy versus Flexible Ureteroscopy/Holmium Laser Lithotripsy: Cost and Outcome Analysis. J. Urol., 182: 1012-17, 2009.

8- PORTIS A.J., LALIBERTE M.A., TATMAN C.A., et al.: Retreatment after percutaneous nephrolithotomy in the computed tomographic era: Long-term follow-up. J. Urol., 84: 279-84, 2014

9- De la ROSETTE J.J., OPONDO D., DAELS F.P., et al.: Categorisation of complications and validation of the Clavien score for percutaneous nephrolithotomy. Eur. Urol., 62: 246-55, 2012.

10- SAMPAIO F.J. and ARAGAO A.H.: Limitations of ESWL for lower caliceal stones; anatomic insight. J. Endourol., 8: 241-47, 1994.

11- CHIBBER P.J.: Percutaneous nephrolithotomy for $1-2 \mathrm{~cm}$ lower-pole renal calculi. Indian J. Urol., 24: 538-43, 2008.

12- AUA Guideline: www.aua2016.org/webcast/clinicalguidelines.cfm

13- EL-NAHAS A.R., ERAKY I. and SHOKAIR A.: Factors Affecting Stone-free Rate and Complications of Percutaneous Nephrolithotomy for Treatment of Staghorn Stone. J. Urol., 79: 1236-41, 2012.

14- SANGUEDOLCE F., BREDA A. and MILLAN F.: Lower pole stones: Prone PCNL versus supine PCNL in the International Cooperation in Endourology (ICE) group experience World J. Urol., 31: 1575-80, 2013.

15- SEITZ C., DESAI M., HÄCKER A., et al.: Incidence, prevention, and management of complications following percutaneous nephrolitholapaxy. Eur. Urol., 61: 146-58, 2012.

16- RASHID A.O. and FAKHULDDIN S: Risk factors for fever and sepsis after percutaneous nephrolithotomy. Arab. J. of Urology, 03.001, 2016.

17- ZHOU Y., ZHU J., GURIOLI A.L., et al.: Randomized Study of Ureteral Catheter vs Double-J Stent in Tubeless Minimally Invasive Percutaneous Nephrolithotomy Patients Journal of Endourol., 31: 278-2, 2017.

18- KARADAG A., CECEN K., DEMIR A., et al: Tubeless Percutaneous Nephrolithotomy: Can be a Choice, Why Not? The Open Urology \& Nephrology Journal, 7: 4-7, 2014.

19- ATMOKO W., BIROWO P. and RASYID N.: Factors affecting stone free rate of primary percutaneous nephrolithotomy on staghorn calculi: A single center experience of 15 years. F1000 Research, 5: 2106-12, 2016.

20- ZHOU X., SUN X. and CHEN X.: Effect of Obesity on Outcomes of Percutaneous Nephrolithotomy in Renal 
Stone Management: A Systematic Review and MetaAnalysis. Urol. Int., 98: 382-90, 2017.

21- ŞIMŞEK A., ÖZGÖR F., AKBULUT M.F., et al.: Does body mass index affect the success of percutaneous nephrolithotomy? Turk J. Urol., 40: 104-9, 2014.

22- S.V. KRISHNA REDDY and BASHA SHAIK A.: Outcome and complications of percutaneous nephrolithotomy as primary versus secondary procedure for renal calculi. Int. Braz J. of Uro., 42:262-69, 2016.

23- SHAH H.N., MAHAJAN A.P., HEGDE S.S., et al.: Tubeless percutaneous nephrolithotomy in patients with previous ipsilateral open renal surgery: A feasibility study with review of literature. J. Endourol., 22: 19-24, 2008.

24- MARGEL D., LIFSHITZ D.A., KUGEL V., et al.: Percutaneous nephrolithotomy in patients who previously underwent open nephrolithotomy. J. Endourol., 19: 116164, 2005.

25- OZGOR1 F., KUCUKTOPCU1 O., SAR1LAR1 O., et al.: Does previous open renal surgery or percutaneousnephrolithotomy affect the outcomes and complicationsof percutaneous nephrolithotomy. Urolithiasis, 43: 541-47, 2015.

26- ZHU Z., WANG S., XI Q., et al.: Logistic regression model for predicting stone-free rate after minimally invasive percutaneous nephrolithotomy. Urology, 78 (1): 32-36, 2011.

27- AKMAN T., BINBAY M., AKCAY M., et al.: Variables that influence operative time during percutaneous nephrolithotomy: An analysis of 1897 cases. BJU Int., 29: 1079-83, 2012.

28- EL-NAHAS A.R., SHOKEIR A.A., EL-ASSMY A.M., et al.: Post-percutaneous nephrolithotomy extensive hemorrhage: A study of risk factors. J. Urol., 177: 576-9, 2007.

29- ANASTASIADIS A., ONAL B., MODI P., et al.: Impact of stone density on outcomes in percutaneous nephro- lithotomy (PCNL): An analysis of the clinical research office of the endourological society (CROES) pcnl global study database. Scan J. Urol., 47: 509-14, 2013.

30- GÜCÜK A., UYETÜRK U., OZTÜRK U., et al.: Does the Hounsfield unit value determined by computed tomography predict the outcome of percutaneous nephrolithotomy? J. Endourol., 26: 792-96, 2012.

31- AMINSHARIF A., ESLAHI A., REZA A., et al.: Stone scattering during percutaneous nephrolithotomy: Role of renal anatomical characteristics. Urolithiasis, 42: 435-40, 2014.

32- RIFAIOGLU M., ÖNEM K. and ÇELIK H.: Does renal parenchymal thickness affect bleeding in percutaneous nephrolithotomy? Turk J. Med. Sci., 43: 878-85, 2013.

33- TEPELER A., BINBAY M., AKMAN T., et al.: Parenchymal thickness: Does it have an impact on outcomes of percutaneous nephrolithotomy? Urol. Int., 90: 405-10, 2013.

34- KARALAR M., TUZEL E., KELES I., et al.: Effects of Parenchymal Thickness and Stone Density Values on Percutaneous Nephrolithotomy Outcomes. Turk J. Med. Sci., 43: 878-85, 2013.

35- FALAHATKAR S., MOGHADDAM K.G., KAZEMNEZHAD E., et al.: Factors affecting operative time during percutaneous nephrolithotomy: Our experience with the complete supine position. J. Endourol., 25: 1831-36, 2011.

36- HUANG S.W., CHANG C.H. and WANG C.J.: Percutaneous nephrolithotomy for the treatment of complete staghorn stones. J. Taiwanese Uro. Ass., 16: 169-73, 2005.

37- YAMAGUCHI A., SKOLARIKOS A., BUCHHOLZ N.P., et al.: Operating times and bleeding complications in percutaneous nephrolithotomy: A comparison of tract dilation methods in 5,537 patients in the Clinical Research Office of the Endourological Society Percutaneous Nephrolithotomy Global Study. J. Endourol., 25: 933-9, 2011. 


\section{العوامل المؤثرة على سلامة وفاعلية منظار الكلى

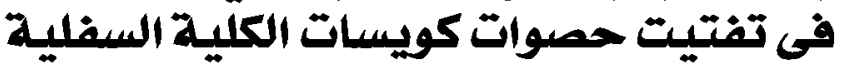

مقدمة البحث: حصوات كويسات الكلى السفلية مازالت تثكل صعوبة فى علاجها وذلك بسبب الموضع التشريحى لها والذى يعتمد أساساً على الجاذبية فى تصريف الحصوات المفتة بحسب الدراسات المسبقة.

الهدف من علاج حصوات كويسات الكلى السفلية هو تصقيق أقصى درجة من ازالة الحصوات المفتتة وباتل المضاعفات الوارد حدوثها لالمريض.

لا يحتاج منظار الكلى إلى معرفة مسبقة بالوضع التثريحى لكويسات الكلية السفلية حيث أنه يحقق أعلى درجة نجاح فى تفتيت الحصوات وازالتها بغض النظر عن طبيعة وشكل الحصوات.

هناك بعض العوامل التى تؤثر على نسب نجاح منظار الكلى أثناء تفتيت حصوات كويسات الكلية السفلية ومن ضمنها حجم إم الحصوة، كثافة الحصوة، عدد الحصوات، تضفم الكلية، سماكة لممية الكلية، مؤشر كثلة الجسم وجراحة مسبقة للكلية.

الهدف من الدراسة: الهدف من هذا العمل تقييم العوامل المؤثرة على سلامة وفعالية منظار الكلى أثناء تفتيت حصوات كويسات الكلية

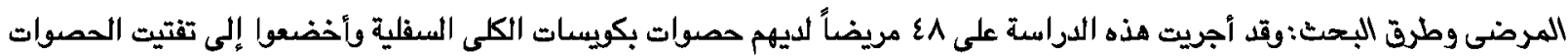

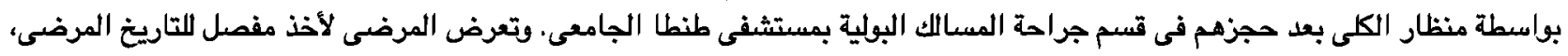

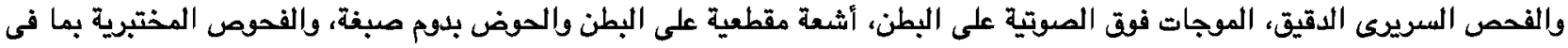

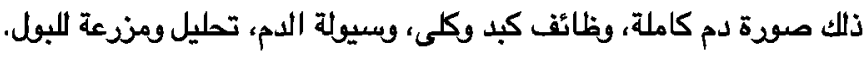

النتائج:ويالنسبة لنتائج الدراسة فقد أظهرت أن حجم وعدد الحصوات، ودرجة تضخم الكية، مدة العملية وأيضاً سمك نسيج الكلية له تأثير

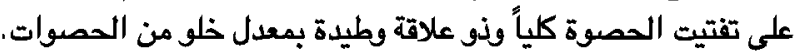

كما أظهرت الدراسة أن حجم الحصوة، سمك نسيج الكلية، درجة تضخم الكلية، جراحة الكلى السابقة وأيضاً مؤشر كتلة الجسم هسئل عن زيادة الانثقاب لحوض وكويسات الكية أنية.

وأيضاً حجم الحموة، درجة تضخم الكلية، مدة العملية، انثقاب حوض وكويسات الكلية وكثافة الحصوة عوامل مسؤلة عن حدوث حمى ما بعد الاجراء الجراحى.

وتبين خلال الدراسة أن حجم الحصوة، جراحة الكلى السابقة، معدل كتلة الجسم، سمك نسيج الكلية ومدة العملية من أهم العوامل المؤئرة

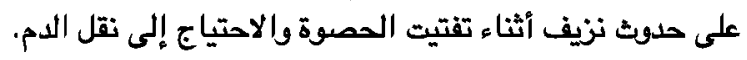

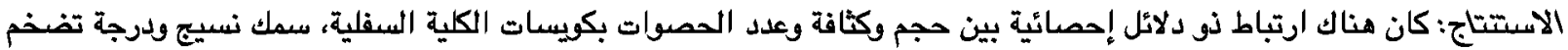

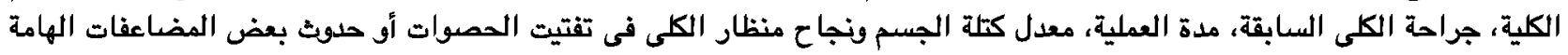

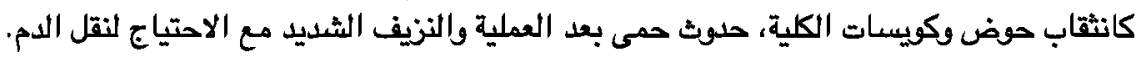

